\title{
Brain-derived Neurotrophic Factor Administration Protects Basal Forebrain Cholinergic but Not Nigral Dopaminergic Neurons from Degenerative Changes after Axotomy in the Adult Rat Brain
}

\author{
Beat Knüsel, ${ }^{1, a}$ Klaus D. Beck, ${ }^{1, a}$ John W. Winslow, ${ }^{2}$ Arnon Rosenthal, ${ }^{2}$ Louis E. Burton, ${ }^{2}$ Hans R. Widmer,' \\ Karoly Nikolics, ${ }^{2}$ and Franz Hefti ${ }^{1}$ \\ 'Division of Neurogerontology, Andrus Gerontology Center, and Department of Biological Sciences, University of Southern \\ California, Los Angeles, California 90089 and ${ }^{2}$ Genentech Inc., South San Francisco, California 94080
}

\begin{abstract}
Cell culture studies with dissociated primary cultures from embryonic rat brain revealed that brain-derived neurotrophic factor (BDNF) promotes the developmental differentiation of both basal forebrain cholinergic and mesencephalic dopaminergic neurons. These studies suggested that, in the adult brain, BDNF may be able to protect cholinergic and dopaminergic neurons from degenerative changes induced by axotomy, similar to the known protective action of NGF in cholinergic neurons. Testing this hypothesis, we found that intraventricular administration of recombinant human BDNF (rhBDNF) to adult rats with transections of the fimbria significantly reduces axotomy-induced degenerative changes of the cholinergic cells in the basal forebrain. No such effect was seen on the dopaminergic neurons of the ventral mesencephalon after transection of their axons ascending in the medial forebrain bundle. Injected in equal amounts, rhBDNF and recombinant human NGF had quantitatively different effects on the cholinergic neurons. BDNF sustained only part of the population of cholinergic neurons affected by the lesion, whereas the entire population was protected by NGF treatment.
\end{abstract}

Concept and definition of neurotrophic factors evolved with the discovery of NGF and the subsequent establishment of its functions in the PNS and CNS (for reviews, see Thoenen et al., 1987; Whittemore and Seiger, 1987; Barde, 1989; Hefti et al., 1989; Oppenheim, 1989; Snider and Johnson, 1989). The best-characterized population of NGF-responsive neurons in the mammalian brain is the group of cholinergic neurons in the basal forebrain. A large body of evidence suggests that NGF promotes, and is necessary for, normal development of these cells (for reviews, sce Thoenen ct al., 1987; Whittemore and Sciger, 1987; Hefti et al., 1989). Roles of NGF during adult life are suggested by presence of NGF protein and mRNA in hippocampus and cortex, target areas of the basal forebrain cholinergic neurons

\footnotetext{
Received Mar. 27, 1992; revised June 3, 1992; accepted June 9, 1992.

We are grateful to Dr. T. H. McNeill (Los Angeles) for his advice regarding cell number analysis. This study was supported by NIH Grants NS22933, AG09793, and AG 10480; NSF Grant BNS-9021255; State of California Alzheimer Program Contract 90-11297; Alzheimer's Association Grant PRG-90-015; and a research grant from the National Parkinson Foundation, Miami, FL. K.D.B. was supported by a postdoctoral fellowship from Deutsche Forschungsgemeinschaft.

Correspondence should be addressed to Dr. F. Hefti, Andrus Gerontology Center, U.S.C., MC-0191, Los Angeles, CA 90089.

The first two authors contributed equally to this report.

Copyright (C) 1992 Society for Neuroscience $0270-6474 / 92 / 124391-12 \$ 05.00 / 0$
}

(Korsching et al., 1985; Rennert and Heinrich, 1986; Shelton and Reichardt, 1986; Ayer-LeLievre et al., 1988). mRNA for an NGF binding protein, the low-affinity NGF receptor (1NGFR), is present in rat basal forebrain (Buck et al., 1987; Higgins et al., 1989), and this protein is colocalized to a high degree with ChAT, the transmitter-specific enzyme of cholinergic neurons (Hefti et al., 1986; Kordower et al., 1988; Schatteman et al., 1988; Yan and Johnson, 1988; Hefti and Mash, 1989). While these findings very strongly suggest that, in the adult basal forebrain, NGF receptors are selectively expressed by cholinergic neurons and that NGF is important for maintenance and continued function of these cells, they need to be reevaluated in light of the recent discovery of protein kinases of the $t r k$ gene family. The protein products of the genes of this family form functional receptors for NGF, brain-derived neurotrophic factor (BDNF), neurotrophin-3 (NT-3), neurotrophin-4, and neurotrophin-5 (Martin-Zanca et al., 1990; Bothwell, 1991; Kaplan et al., 1991a,b; Soppet et al., 1991; Squinto et al., 1991). Trk mRNA is found in basal forebrain (Vazquez and Ebendahl, 1991). Further, recent data indicates that l-NGFR binds other neurotrophins than NGF with similar affinity (Rodriguez-Tebar et al., 1990, 1992) and it seems possible that this protein might participate in the formation of functional highaffinity receptors for various neurotrophins.

The basal forebrain cholinergic neurons are prominently involved in the pathology of Alzheimer's disease, and the decline of cholinergic function and cholinergic markers in the septohippocampal and basalocortical projection represents one of the most consistent changes in the disease process. It is believed to be responsible, in part, for the behavioral deficits characterizing the disease (for reviews, see Price, 1986; Olton, 1990; Dekker et al., 1991). This cholinergic deficit is mimicked by lesions of the cholinergic septohippocampal pathway in the adult rat brain. The lesion-induced degenerative changes are prevented by intraventricular administration of NGF. In particular, fimbrial transections result in the loss of neuronal profiles seen in Nissl stain and disappearance of cholinergic neuron-specific markers, ChAT and l-NGFR, and these changes are prevented by chronic intraventricular administration of NGF (Ilefti et al., 1986; Williams et al., 1986; Kromer, 1987; Gage et al., 1988; Montero and Hefti, 1988; Koliatsos et al., 1991). NGF infusions also stimulate the expression of ChAT and l-NGFR mRNAs by remaining cholinergic neurons (Higgins et al., 1989; Vantini et al., 1990). Partial fimbrial transections used in some of these studies result in a partial reduction of the activity of ChAT in 
the hippocampus and the ability of hippocampal slices to synthesize and release $\mathrm{ACh}$. These reductions in hippocampal presynaptic cholinergic function are also counteracted by intraventricular administration of NGF (Hefti et al., 1984; Williams et al., 1989; Lapchak and Hefti, 1991; Lapchak et al., 1992). The action of NGF is selective for cholinergic neurons inasmuch as NGF treatment failed to prevent the loss of septohippocampal GABAergic neurons or dopaminergic nigrostriatal neurons after axotomy (Montero and Hefti, 1988; Hefti, 1989). Based on such findings, the experimental use of NGF in the treatment of $\mathrm{Al}$ zheimer's disease has been suggested (Phelps et al., 1989) and initial trials have been reported (Olson et al., 1992).

Degeneration of dopaminergic neurons of the substantia nigra is characteristic for Parkinson's disease and, unlike the loss of cholinergic cells in Alzheimer's disease, which is one among several characteristic pathological attributes, most likely represents a single key feature responsible for the majority of behavioral deficits of the disease (for reviews, see Albin et al., 1989; Marsden, 1990; Agid, 1991). Identification of a trophic factor for these neurons, therefore, would be most likely to have great impact on the future treatment of Parkinson's disease. Accordingly, the search for a molecule able to protect dopaminergic cell bodies in animals with experimental lesions, resembling the protective effects of NGF on septohippocampal cholinergic cells, is a major goal of many investigators.

NGF, due to a relatively abundant natural source in the mouse submaxillary glands, has been available for experimental work for several years. BDNF only recently became available through recombinant techniques in sufficient quantities for extensive studies. Cell culture work with recombinant human BDNF (rhBDNF) has shown effects of this factor on several neuronal cell populations. In cholinergic cultures, rhBDNF, similar to recombinant human NGF (rhNGF), increases ChAT activity and intensity of ChAT immunocytochemical staining, suggesting that it upregulates the expression of ChAT in individual cholinergic neurons (Alderson et al., 1990; Knüsel et al., 1991). Maximal responsiveness to rhBDNF and rhNGF are differently timed in these neurons with pronounced early response to rhBDNF (Knüsel et al., 1991). In contrast to rhNGF, rhBDNF also affects ChAT activity in cholinergic neurons of the pons and GABA uptake in the septal cultures and exerts a pronounced stimulatory effect on dopamine uptake in mesencephalic cultures (Hyman et al., 1991; Knüsel et al., 1991; Beck et al., 1992). Besides the actions on central cholinergic and dopaminergic neurons, BDNF affects sensory neurons (Hofer and Barde, 1988; Leibrock et al., 1989; Maisonpierre et al., 1990; Rosenthal et al., 1991) and retinal ganglion cells (Johnson et al., 1986; Thanos et al., 1989).

BDNF mRNA is predominantly localized to the brain and is considerably more abundant there than mRNA for NGF (Leibrock et al., 1989; Ernfors et al., 1990; Hofer et al., 1990). Even though present in many areas of the adult rat brain, BDNF mRNA is heterogeneously distributed with a particularly high prevalence in the hippocampus (Hofer et al., 1990; Phillips et al., 1990). Recent publications suggest that the protein product of $t r k \mathrm{~B}$, a $t r k$-related gene, codes for a functional BDNF receptor (Glass et al., 1991; Klein et al., 1991; Soppet et al., 1991; Squinto et al., 1991) and trkB mRNA seems to be exclusively expressed in the CNS and PNS (Klein et al., 1990b). These findings suggest that BDNF plays an important role in the function of many populations of brain neurons and, conceivably, non-neuronal cells, possibly as a pluripotent, brain-specific growth factor. Based on such spcculations and the cell culturc findings indicating an action on developing cholinergic and dopaminergic neurons, we decided to test whether exogenous rhBDNF, administered by repeated intracerebroventricular injections, prevents degenerative changes of basal forebrain cholinergic neurons or nigral dopaminergic neurons after axonal transections in adult rats.

\section{Materials and Methods}

Surgical lesions. Female Wistar rats (180-200 gm; Charles River) were used for these studies (total number, 85). The rats were anesthetized with $75 \mathrm{mg} / \mathrm{kg}$ Nembutal and positioned in a stereotaxic apparatus (Kopf Instruments, Tuyunga, CA) to conform with the brain atlas of Paxinos and Watson (1986). Partial fimbrial transections were produced using a modification of a previously described procedure (Montero and Hefti, 1988). A retractable wire knife (Scouten knife, Kopf Instruments, Tuyunga, CA) was used rather than the microblade utilized earlier (Fig. 1). A small slit was drilled into the skull, extending from lateral $0.7 \mathrm{~mm}$ and posterior $1.9 \mathrm{~mm}$ from bregma to lateral $1.9 \mathrm{~mm}$ and posterior 2.5 $\mathrm{mm}$ from bregma. The rostromedial end of the slit was to accommodate the knife for the lesion, and the caudolateral end was to receive the guiding cannula for the injection system (see below). The tip of the retracted knife was advanced into the brain to $1.9 \mathrm{~mm}$ posterior, 0.7 $\mathrm{mm}$ lateral, and $6.0 \mathrm{~mm}$ ventral of bregma. The following manual steps were performed to execute the lesion: extend knife blade $2 \mathrm{~mm}$, raise knife by $4.5 \mathrm{~mm}$ to $1.5 \mathrm{~mm}$ below bregma, retract and extend knife blade again, lower knife by $4.5 \mathrm{~mm}$, raise knife by $4.5 \mathrm{~mm}$, retract blade, and remove knife. This sequence of retracting, extending, and moving the knife blade ascertained that the lesion of the lateral part of the rather flexible fimbria was complete throughout its dorsoventral extent and, furthermore, minimized cortical and striatal cuts associated with the earlier-used procedure.

For the medial forebrain bundle (MFB) lesions, the retractable knife was lowered through a drill hole $3.8 \mathrm{~mm}$ postcrior and $2.4 \mathrm{~mm}$ lateral of bregma to a ventral position of $8.0 \mathrm{~mm}$ below bregma. The blade was extended by $2.0 \mathrm{~mm}$ and the knife was slowly moved upward by $2.5 \mathrm{~mm}$, and subsequently down again by $2.5 \mathrm{~mm}$. The blade was then retracted and the knife withdrawn.

Intraventricular injections of growth factors. The preparation of rhBDNF that was used in the present study was produced in a Chinese hamster ovary cell line as described in detail previously (Rosenthal et al., 1991). Over $90 \%$ of the rhBDNF protein was full length as confirmed by $\mathrm{N}$-terminal sequence analysis and mass spectrometry (data not shown). Recombinant human NGF (rhNGF) was produced and characterized as described in Knüsel et al. (1990b). For intraventricular injections, an injection system from Plastics One Inc. (Roanoke, VA) was used. A metal guiding cannula ( 22 gauge) with threaded plastic casing was permanently attached to the skull with miniature screws and dental ccment. The intracerebral end of the guiding cannula was placed $2.5 \mathrm{~mm}$ posterior, $1.9 \mathrm{~mm}$ lateral, and $4.0 \mathrm{~mm}$ below bregma. The injections, therefore, were into the ventricular space dorsal to the anterior pole of the hippocampus (Fig. 1). Between injections, the guiding cannula was closed with a solid dummy cannula. For intraventricular injections, the dummy cannula was replaced temporarily by a small-bore ( 28 gauge) metal cannula protruding $0.5 \mathrm{~mm}$ from the internal end of the guiding cannula. This cannula was connected by flexible tubing to a Hamilton syringe containing rhBDNF, rhNGF, or cytochrome $C$ serving as control protein (Hefti et al., 1984). The proteins were dissolved in $0.01 \mathrm{~m} \mathrm{Na}$-succinate, $0.14 \mathrm{M} \mathrm{NaCl}$ with $15 \mathrm{mg} / \mathrm{ml}$ gentamicin, and $2.5 \mu \mathrm{l}$ of the solutions were injected over a time period of $90 \mathrm{sec}$. Since the pH of the injected solutions was adjusted to 7.4 with $1 \mathrm{~N} \mathrm{NaOH}$, undiminished bioactivity of the growth factors after completion of the experimental treatment was verified in basal forebrain cultures (data not shown). For intraventricular injections of rats with MFB lesions, the position of the guiding cannula was identical to that used for animals with fimbrial transections. For local injection at the lesion site, the intracerebral end of the guiding cannula was placed $3.8 \mathrm{~mm}$ posterior, $1.4 \mathrm{~mm}$ lateral, and $7.5 \mathrm{~mm}$ below bregma. For intranigral injections, the corresponding coordinates were $5.2 \mathrm{~mm}$ posterior, $1.5 \mathrm{~mm}$ lateral, and $8.3 \mathrm{~mm}$ below bregma. In all injection paradigms, the tip of the injection needle protruded by 0.5 $\mathrm{mm}$ from the tip of the guiding cannula. The first injection of growth factor was given at the day of lesioning, and animals were taken for analysis $1 \mathrm{~d}$ after the last administration. Treatment periods were $18 \mathrm{~d}$ for MFB-lesioned animals and $20 \mathrm{~d}$ for fimbria-lesioned animals.

Immunohistochemistry and cell number analysis. The rats were per- 
fuscd through the heart under deep anesthesia (Nembutal) with $100 \mathrm{ml}$ of PBS containing $10 \mathrm{U} / \mathrm{ml}$ heparin followed by $50-100 \mathrm{ml}$ of $4 \%$ paraformaldehyde in phosphate buffer, $\mathrm{pH}$ 7.4. The brains were removed, postfixed for $24 \mathrm{hr}$ in the same fixative, and then immersed in sucrose in phosphate buffer, pH 7.4, first in $10 \%$ sucrose for $24 \mathrm{hr}$ and then in $30 \%$ sucrose until sunk $(2-5 \mathrm{~d})$. The brains were blocked for frontal sectioning according to the rat brain atlas of Paxinos and Watson (1986). Frozen sections $(45 \mu \mathrm{m})$ were cut on a sliding microtome and collected into PBS containing $0.02 \% \mathrm{NaN}_{3}$. From fimbria-lesioned animals, all sections containing the vertical limb of the diagonal band of Broca or the medial septal nucleus were collected; from MFB-lesioned animals, all sections spanning the substantia nigra were collected.

Cholinergic and dopaminergic cell bodies were visualized, respectively, by ChAT and tyrosine hydroxylase (TH) immunohistochemistry. Primary antibodies were a mouse monoclonal antibody against rat ChAT (gift from Dr. P. Salvaterra, City of Hope, Duarte, CA) and rabbit polyclonal IgGs against PC12 cell TH (gift from Dr. J. Reinhard, Burroughs Wellcome Co., Research Triangle Park, NC), respectively. For ChAT, all incubations and washes were in Tris buffer, $\mathrm{pH}$ 7.3; for TH, PBS was used throughout the procedure. Sections were washed twice and then incubated for $24-48 \mathrm{hr}$ at $4^{\circ} \mathrm{C}$ with primary antibody. To block unspecific binding, $2 \%$ horse serum (ChAT) or $1 \%$ goat serum $(\mathrm{TH})$ was present in the incubation medium for the primary antibody. The primary incubation medium for TH also contained $2 \%$ bovine serum albumin, $0.2 \%$ Triton $\mathrm{X}-100$, and $0.02 \% \mathrm{NaN}_{3}$. Subsequent incubations at room temperature were with $1 \%$ biotinylated anti-mouse IgG (ChAT; IgG affinity purified and rat adsorbed) or $1 \%$ anti-rabbit IgG (TH) and then with a preformed conjugate of avidin and biotinylated horseradish peroxidase (all reagents by Vector Laboratorics, Burlingame, CA). The peroxidase was visualized with a standard diaminobenzidine/hydrogen peroxide chromogen reaction.

ChAT-positive or TH-positive cell bodies were counted by a naive observer in every sixth section throughout the entire rostrocaudal extent of the medial septum and the substantia nigra, respectively. Statistical analysis of control animals determined that this counting procedure allowed us to estimate the total number of cells in these structures with an error of less than 5\% (data not shown). Cell bodies with a recognizable nucleus and at least one neuritic process were counted. In the septal area, ChAT-positive cells were counted in the medial septal nucleus and vertical limb of the diagonal band of Broca as defined by McKinney et al. (1983). This area was delineated by the following borders: between the anteriormost part of the medial septal nucleus and the medial portion of the anterior commissure and dorsal of a line connecting the ventral surface of the two branches of the anterior commissure. The anterior and posterior borders correspond to levels, respectively, $1.6 \mathrm{~mm}$ and $-0.4 \mathrm{~mm}$ from bregma according to the atlas of Paxinos and Watson (1986). Dopaminergic neurons were counted in two areas defined as follows: area 1 (A9 + A8, substantia nigra), defined as the area lateral to the medial tip of the lemniscus medialis, and area 2 (A10), medial to the medial tip of the lemniscus medialis (Lindvall and Bjorklund, 1983). The anterior and posterior borders correspond to levels, respectively, $4.5 \mathrm{~mm}$ and $6.3 \mathrm{~mm}$ from bregma according to the atlas of Paxinos and Watson (1986). Statistical significance was assessed using analysis of variance followed by Student's unpaired $t$ test.

Dose-response studies on cell cultures and stability of growth factors. Cultures were prepared from fetal rat (Wistar, aged embryonic day 1516; Charles River) basal forebrain and taken for analysis of ChAT activity as described in detail elsewhere (Knüsel et al., 1990a,b, 1991). The nonlinear procedure of the RS/1 data analysis system (BBN Software Products Corp., Cambridge, MA) was used to fit the equation $Y$ $=A+B /\left[1+(C / X)^{* *} N\right]$ to the ChAT data and to establish $\mathrm{EC}_{50}$ values for rhBDNF and rhNGF. In this equation, $A$ represents $C h A T$ activity of untreated control cultures, $B$ represents the maximal growth factorinduced increase, $C$ is the $\mathrm{EC}_{50}$ value, and $N$ is the value for the slope. To ascertain stability of both rhBDNF and rhNGF in the solutions used for intraventricular injections, aliquots were tested after completion of the injections in this cell culture system. The bioactivity of both proteins was found not to have declined by $>20 \%$ through the course of the study.

\section{Results}

\section{Effects of lesions}

Precisely defined unilateral, partial transections of the fimbria, or, in other animals, transections of the MFB were performed
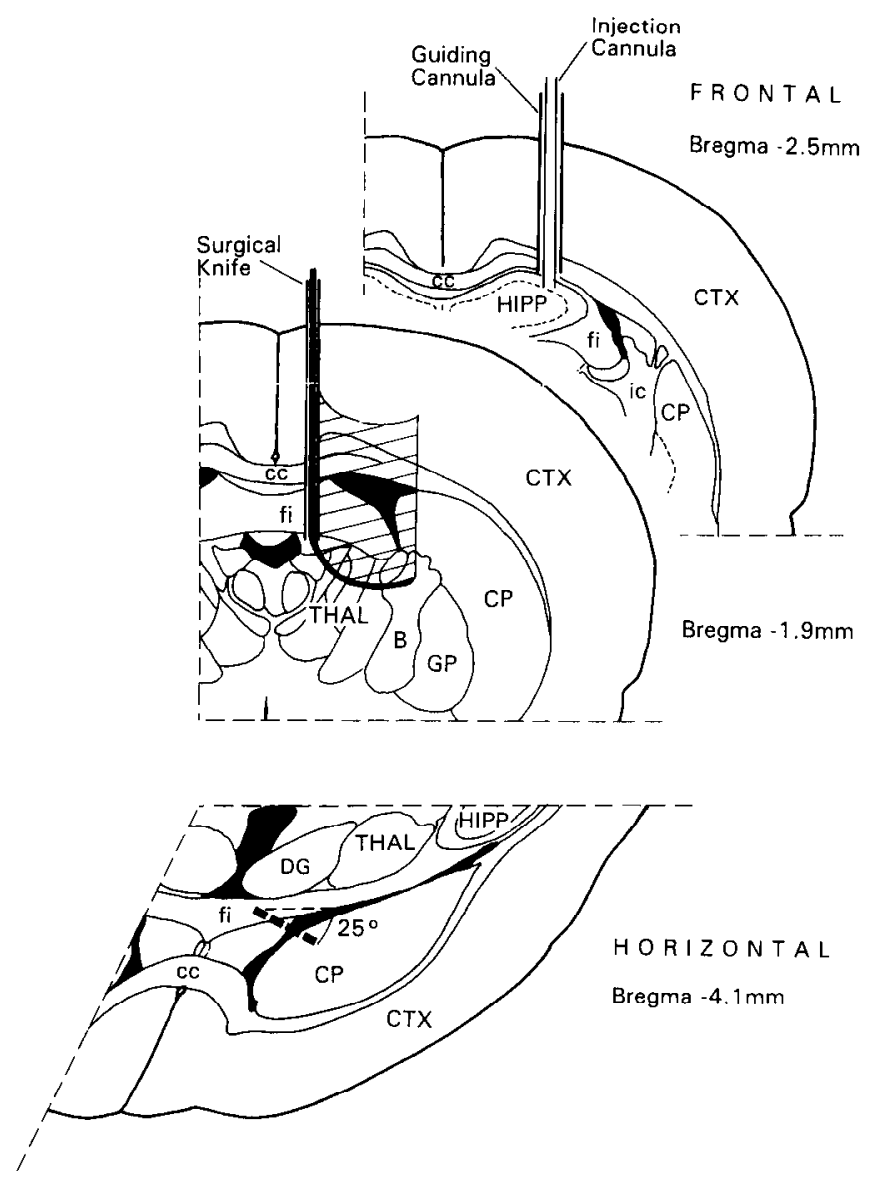

Figure 1. Partial fimbrial transection and implantation of a cannula for chronic intracerebroventricular injection of growth factors. The lateral $70-80 \%$ of the fimbria was stereotactically transected as described in Materials and Methods using a retractable wire knife. Note the angle of the cut of $25^{\circ}$ to the coronal plane as indicated in the horizontal view. This angle ascertains a complete transection of the lateral part of the fimbria with minimal length of the knife cut. In the same surgical session, a guiding cannula was implanted through which a smaller injection cannula could be temporarily inserted with its tip at determined brain coordinates $0.5 \mathrm{~mm}$ beyond the internal end of the guiding cannula for repeated injections of growth factors. Between injections, the guiding cannula was closed with a wire of the same dimensions as the injection cannula (dummy cannula). $B$, nucleus basalis of Meynert; $c c$, corpus callosum; $C P$, caudate putamen; $C T X$, cortex; $D G$, dentate gyrus; $f$, fimbria; $G P$, globus pallidus; $H I P P$, hippocampus; $i c$, internal capsule; $T H A L$, thalamic nuclei.

using an retractable wire knife. The fimbrial transections cut the lateral $70-80 \%$ of the fimbrial cross section at an anteroposterior level adjacent to the rostral pole of the hippocampus (Fig. 1). After $20 \mathrm{~d}$, the transection resulted in a loss of the total number of ChAT-positive cell bodies in the medial septal nucleus and the vertical limb of the diagonal band of Broca on the lesioned side of cytochrome C-treated control animals to $41 \%$ of the numbers on the unlesioned control side (Table 1; see Figs. 3, 4). The $20 \mathrm{~d}$ survival period was chosen based on earlier studies revealing that the degenerative changes in the septal area visible with specific stainings for the cholinergic cell bodies are complete 2 weeks after fimbrial transections (Hefti, 1986; Montero and Hefti, 1988). In corroboration of earlier findings (Schwaber et al., 1991), the cell loss was evident throughout the entire rostrocaudal extent of the septal area but was more pronounced in its caudal part (see Fig. 4), and, furthermore, the unilateral 
Table 1. Total numbers of cholinergic cell bodies in medial septum of control and growth factor-treated rats

\begin{tabular}{llll}
$\begin{array}{l}\text { Experimental } \\
\text { group }\end{array}$ & $\begin{array}{l}\text { Unlesioned } \\
\text { side }\end{array}$ & $\begin{array}{l}\text { Lesioned } \\
\text { side }\end{array}$ & $\begin{array}{l}\text { \% Lesioned/ } \\
\text { unlesioned }\end{array}$ \\
\hline Control (13) & $1967 \pm 83$ & $784+50$ & $40.5 \pm 4.7$ \\
rhBDNV 0.7 $\mu \mathrm{g} \mathrm{(13)}$ & $2195 \pm 99$ & $1283 \pm 84^{a}$ & $59.1 \pm 4.1$ \\
rhNGF 0.7 $\mu \mathrm{g} \mathrm{(9)}$ & $1909 \pm 97$ & $1806 \pm 116^{a}$ & $95.0 \pm 4.7$ \\
$\operatorname{rhBDNF~4.5} \mu \mathrm{g} \mathrm{(7)}$ & $2328 \pm 112$ & $1606 \pm 128^{a}$ & $69.0 \pm 4.6$ \\
rhNGF 0.05 $\mu \mathrm{g} \mathrm{(6)}$ & $2237 \pm 223$ & $1818 \pm 147^{a}$ & $82.2 \pm 3.7$
\end{tabular}

ChAT-positive cell bodies were counted in the medial septal nucleus and the vertical limb of the diagonal band of Broca as defined in Materials and Methods. For intraventricular injections, the amounts given in the table were injected in $2.5 \mu \mathrm{l}$ vehicle daily during $20 \mathrm{~d}$. Given are mean $\pm \mathrm{SEM}$; numbers of animals per group are in parentheses.

${ }^{a}$ Different from lesioned side of controls (Student's $t$-test $p<0.01$ ); the apparent difference between treatment with $0.05 \mu \mathrm{g}$ rhNGF and $4.5 \mu \mathrm{g}$ rhBDNF is statistically not significant.

lesions did not reduce the number of ChAT-positive cell bodies on contralateral sides when compared to nonlesioned control animals (data not shown).

The MFB transection (Fig. 2) was designed to cut the majority of axons of the mesencephalic dopaminergic neurons at a distance of the cell bodies approximately equivalent to that imposed by the fimbrial transections on cholinergic neurons (Fig. 1). This MFB transection avoids the massive destruction of many other brain areas associated with the hemitransections used by other investigators to cut nigrostriatal dopaminergic axons (Agnati et al., 1983). In confirmation of these earlier studies, our MFB lesion reduced the number of TH-positive cell bodies in both the substantia nigra (dopaminergic cell groups A9 + A8; Lindvall and Bjorklund, 1983) and the medioventral mesencephalic area (A10), respectively, to $44 \%$ and $57 \%$ of the numbers on control sides (Table 2). Independent experiments revealed that the unilateral MFB lesions did not significantly

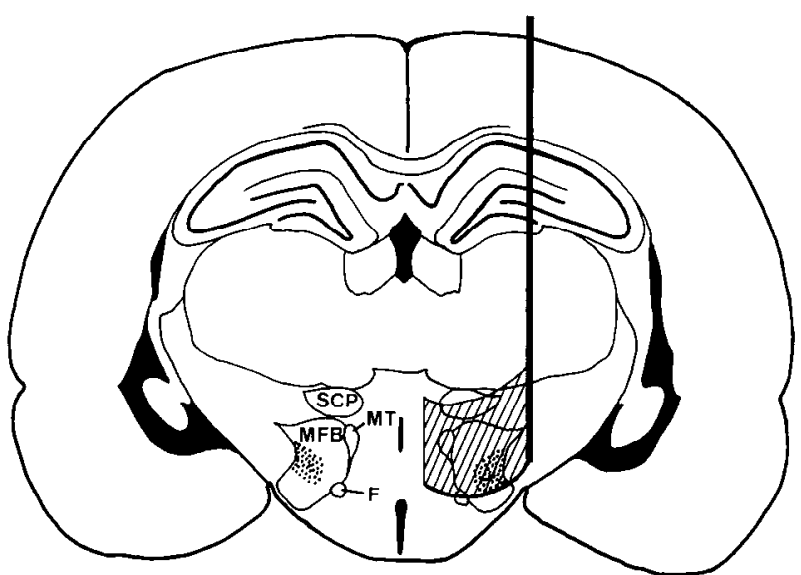

Figure 2. MFB transection resulting in axotomy of dopaminergic neurons in the substantia nigra. The lesion was performed stereotactically with the same retractable wire knife as used for the partial fimbria lesions. A guiding cannula identical to the one used in fimbria transections was implanted in the MFB-lesioned animals for intraventricular injections of rhBDNF or, alternatively, injections at the sile of the lesion or within the substantia nigra. $F$, fornix; $M F B$, medial forebrain bundle; $M T$, mammillothalamic tract; $S C P$, superior cerebellar peduncle.

reduce the number of contralateral $\mathrm{TH}$-positive cell bodies as compared to cell numbers in unlesioned animals (data not shown), confirming earlier findings that indicated that the vast majority of dopaminergic axons from the mesencephalon innervate ipsilateral forebrain areas (Fallon and Loughlin, 1985).

\section{$B D N F$ protection against cholinergic degeneration after fimbrial transections}

Intraventricular administration of rhBDNF to animals with fimbrial transection significantly reduced the lesion-induced loss of ChAT-positive cell bodies in the medial septum and vertical

Table 2. Total numbers of TH-positive cell bodies in substantia nigra (dopaminergic cell groups A8 + A9) and medioventral mesencephalic area (group A10) of control and rhBDNF-treated rats with MFB lesions

\begin{tabular}{|c|c|c|c|c|}
\hline \multicolumn{2}{|c|}{ Experimental group } & Unlesioned side & Lesioned side & $\begin{array}{l}\text { \% Lesioned/ } \\
\text { unlesioned }\end{array}$ \\
\hline \multicolumn{5}{|c|}{ Intraventricular injections } \\
\hline \multirow[t]{2}{*}{$\mathrm{A} 9+\mathrm{A} 8$} & Control (5) & $3969 \pm 360$ & $1680 \pm 191$ & $44.2 \pm 6.5$ \\
\hline & rhBDNF (7) & $3521 \pm 286$ & $1620 \pm 222$ & $40.3 \pm 3.6$ \\
\hline \multirow[t]{2}{*}{ A10 } & Control & $2325 \pm 307$ & $1272 \pm 200$ & $55.8 \pm 7.4$ \\
\hline & rhBDNF & $2822 \pm 316$ & $1808 \pm 310$ & $63.6 \pm 10.5$ \\
\hline \multicolumn{5}{|c|}{ Injections at lesion site } \\
\hline \multirow[t]{2}{*}{$\mathrm{A} 9+\mathrm{A} 8$} & Control (6) & $5712 \perp 383$ & $2922 \perp 376$ & $51.8 \pm 7.0$ \\
\hline & $\operatorname{rhBDNF}(6)$ & $5399 \pm 289$ & $3184 \pm 341$ & $59.6 \pm 6.7$ \\
\hline \multirow[t]{2}{*}{ A 10} & Control & $3190 \pm 190$ & $2072 \pm 207$ & $64.6 \pm 4.8$ \\
\hline & rhBDNF & $2891 \pm 161$ & $1766 \pm 119$ & $61.0 \pm 1.4$ \\
\hline \multicolumn{5}{|c|}{ Injections into substantia nigra } \\
\hline \multirow[t]{2}{*}{$\mathrm{A} 9+\mathrm{A} 8$} & Control (7) & $5054 \pm 884$ & $2334 \pm 202$ & $55.2 \pm 5.5$ \\
\hline & rhBDNF (6) & $4301 \pm 335$ & $2240 \pm 347$ & $54.6 \pm 1.7$ \\
\hline \multirow[t]{2}{*}{ A 10} & Control & $2897 \pm 151$ & $1644 \pm 61$ & $57.4 \pm 4.0$ \\
\hline & rhBDNF & $3107 \pm 211$ & $1944 \pm 217$ & $65.7 \pm 2.8$ \\
\hline
\end{tabular}

For intraventricular injections, $0.58 \mu \mathrm{g}$ of rhBDNF was injected every second day during $18 \mathrm{~d}$. For local or intranigral administration, $0.224 \mu \mathrm{g}$ was injected daily during $18 \mathrm{~d}$. The reductions in cell numbers on lesioned sides were statistically significant in all groups (Student's $t$-test, $p<0.01$ ). Results were obtained in three independent experiments. No significant differences were observed between control and rhBDNF-treated groups. Given are mean \pm SEM; numbers of animals per experimental group are in parentheses. 

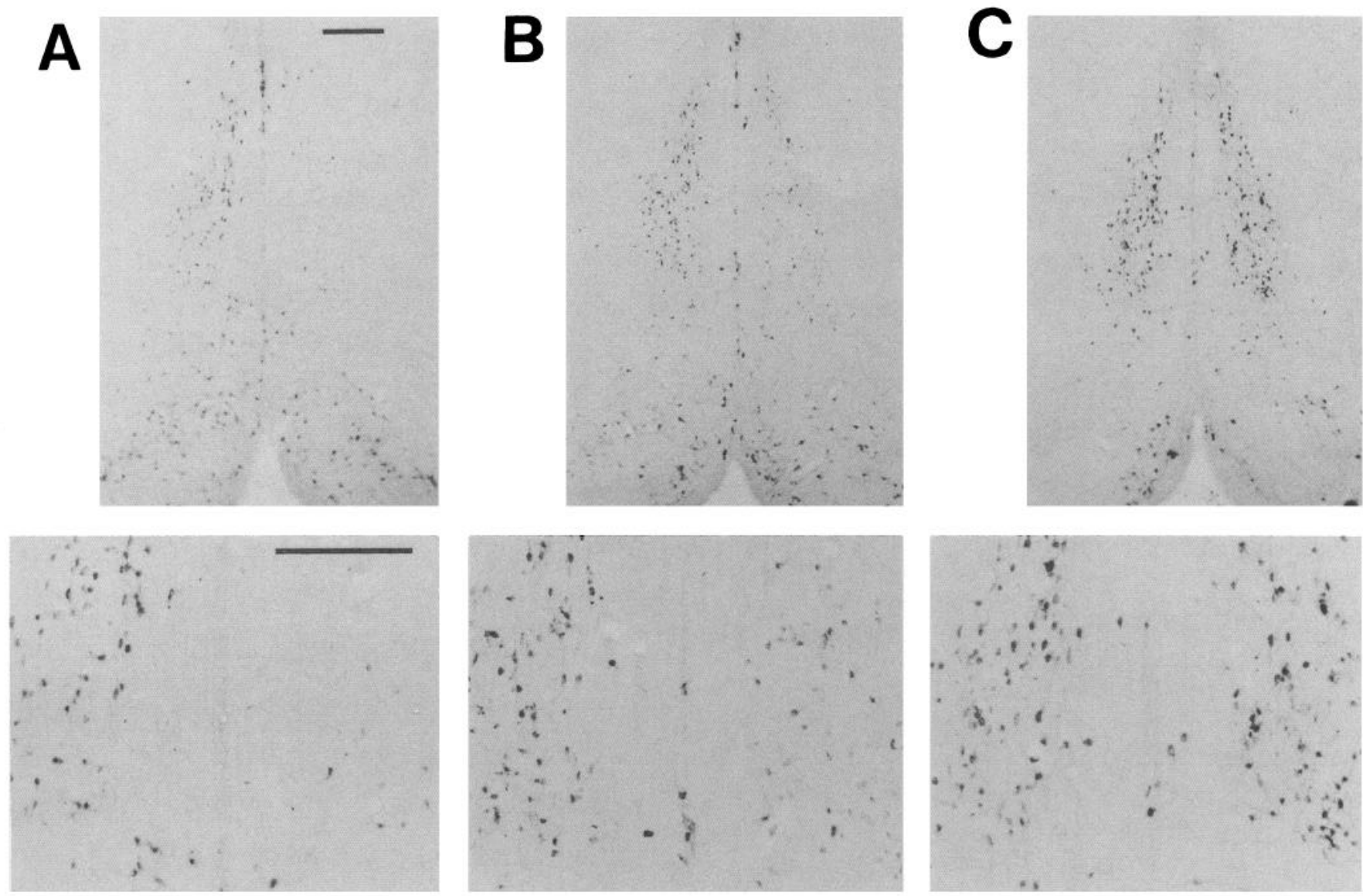

Figure 3. Photomicrographs of frontal sections through the medial septum stained by immunocytochemistry with a monoclonal antibody against ChAT. In five groups of rats, unilateral partial fimbria lesions were performed. The groups received daily intracerebroventricular injections of cytochrome C $(0.7 \mu \mathrm{g}$, controls), rhBDNF $(0.7 \mu \mathrm{g}$ or $4.5 \mu \mathrm{g})$, or rhNGF $(0.05 \mu \mathrm{g}$ or $0.7 \mu \mathrm{g})$. After $20 \mathrm{~d}$, the animals were killed and the cholinergic cells in the medial septum were counted after ChAT immunostaining. The right sides in the photomicrographs correspond to the lesioned side of the brain. $A$, cytochrome C-treated animal (control); $B$, rhBDNF-treated animal ( $4.5 \mu \mathrm{g}$ daily); $C$, rhNGF-treated animal $(0.7 \mu \mathrm{g}$ daily). Note the pronounced loss of ChAT-positive cell bodies on the lesioned side of the cytochrome C-treated control animal, the significantly reduced loss in the rhBDNF-treated animal, and the essentially complete protection against cell loss in the rhNGF-treated animal. Magnification: upper panels, $40 \times$; lower panels, $160 \times$. Scale bars, $250 \mu \mathrm{m}$.

limb of the diagonal band (Table 1; Figs. 3, 4). rhNGF was used as a positive control in these studies and, in confirmation of earlier findings, resulted in almost full protection of the ChATpositive cell bodies. When rhBDNF and rhNGF were injected at the same dose $(0.7 \mu \mathrm{g}$ injected daily, $14 \mu \mathrm{g}$ total; a dose chosen based on earlier experience with rhNGF) rhBDNF was less effective than rhNGF. On the lesioned side of rhBDNF-treated animals, $59 \%$ of the cholinergic cell bodies remained after 20 d, as compared to $95 \%$ remaining cells on lesioned sides of animals treated with rhNGF and $41 \%$ on lesioned sides of cytochrome C-treated rats (Table 1). No significant effect of either growth factor treatment was observed for the number of ChATpositive cell bodies on unlesioned sides.

It seemed possible that the protective effect of rhBDNF was less than that of rhNGF because its dose might have been submaximal. In earlier cell culture studies, rhBDNF was found to be less potent than rhNGF in elevating ChAT activity of developing septal cholinergic neurons (Knüsel et al., 1990b, 1991). Therefore, in another group of animals, a dose of rhBDNF (4.5 $\mu \mathrm{g}$ daily) was injected that was the maximal permissible amount given the technical constraints of the preparation of the injection solution. The equipotent dose of NGF on basal forebrain cholinergic neurons in culture was determined with the same prep-

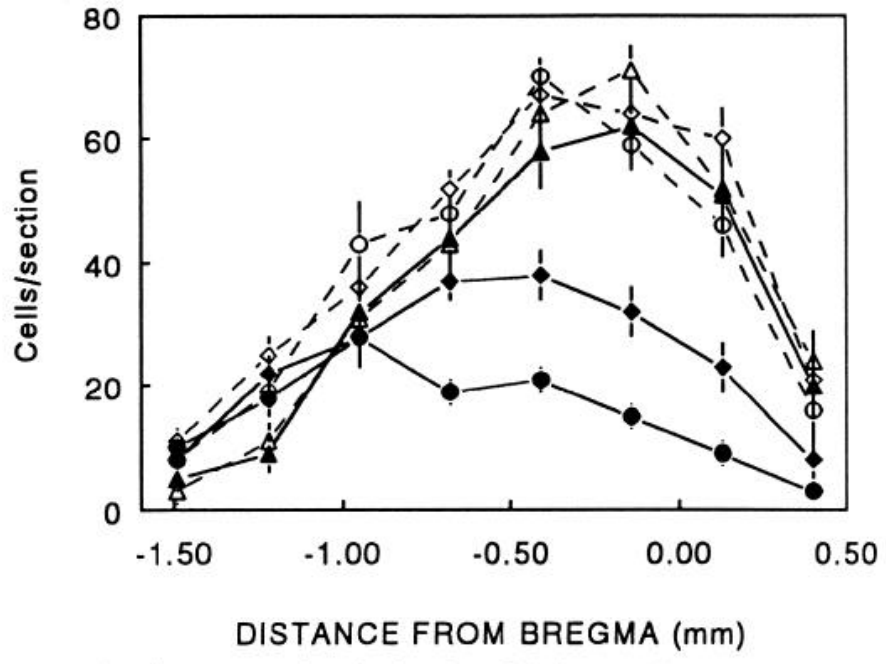

Figure 4. Anteroposterior distribution of ChAT-positive neurons within the medial septal nucleus and the vertical limb of the diagonal band of Broca. rhBDNF and rhNGF $(0.7 \mu \mathrm{g})$ reduced the lesion-induced cholinergic cell loss over the entire extent of the medial septum. Unlesioned side: $\mathrm{O}$, control; $\diamond$, rhBDNF; $\Delta$, rhNGF. Lesioned side: $\bullet$, control; $\diamond$, rhBDNF; $\boldsymbol{\Delta}$, rhNGF. Means \pm SEM are shown; numbers of animals per group are as given in Table 1 . 


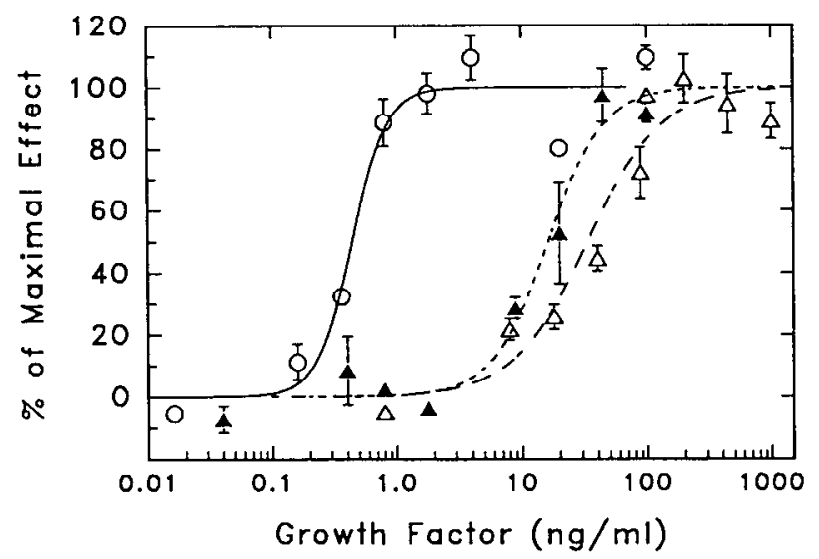

Figure 5. Dose-response curves in vitro for the preparation of rhBDNF and rhNGF used in vivo. Primary cultures of embryonic rat septal or mescncephalic cells were grown as described elsewhere (Knüsel et al., 1990a,b, 1991). Cultures were grown for $7 \mathrm{~d}$, exposed to the growth factors for the last $5 \mathrm{~d}$, and then taken for analysis of ChAT activity or dopamine uptake, respectively. Dose-response curves were calculated as described in Materials and Methods. $O$, rhNGF, cholinergic neurons; $\triangle$, rhBDNF, cholinergic neurons; $\Delta$, rhBDNF, dopaminergic neurons. In septal cultures, $\mathrm{EC}_{50}$ values for $\mathrm{ChAT}$ activity were measured to be 39.4 and $0.44 \mathrm{ng} / \mathrm{ml}$, for rhBDNF and rhNGF, respectively, indicating that rhBDNF is approximately 90 times less potent than rhNGF in culture. In mesencephalic cultures, the $\mathrm{EC}_{50}$ value for the BDNF-induced stimulation of dopamine uptake was $16.2 \mathrm{ng} / \mathrm{ml}$. Data points represent means \pm SEM of 3-4 individual culture wells.

arations of rhBDNF and NGF as used for the in vivo injections (Fig. 5). rhNGF in these experiments was found to be approximately 90 times more potent in stimulating ChAT activity than rhBDNF. Therefore, the effect of the maximal dose of rhBDNF used in vivo (4.5 $\mu \mathrm{g}$ daily, $90 \mu \mathrm{g}$ total) was compared with an equipotent dose of $50 \mathrm{ng}$ daily $(1 \mu \mathrm{g}$ total) of rhNGF. Even at this high dose, rhBDNF failed to protect the population of cholinergic neurons fully (Table 1). The number of ChAT-positive neurons on the lesioned side was $69 \%$ of the value on the control side of these animals. In rats treated with $50 \mathrm{ng}$ of NGF daily, the number of ChAT-positive cells on the lesioned side was $82 \%$ of the unlesioned side. However, the numbers of cholinergic cell bodies on lesioned and unlesioned side did not differ significantly between the animal groups receiving these respective amounts of rhBDNF or rhNGF (Table 1). These findings indicate that rhBDNF is less potent and, possibly, less effective than rhNGF in protecting septal cholinergic cell bodies from axotomy-induced degenerative changes. Visual observation of stained sections suggested that the intensity of ChAT immunohistochemical staining was elevated in rhNGF-treated animals on both lesioned and unlesioned sides. No comparable effect was observed in rhBDNF-treated rats (Fig. 3). Standardized cell counting methods were used to test whether rhBDNF is effective on a regionally defined subpopulation of septal cholinergic neurons. These studies revealed a partial protective effect of the rhBDNF injections over the entire rostrocaudal extent of the medial septum (Fig. 4).

Failure of rhBDNF treatment to protect dopaminergic neurons after MFB transections

The preparation of rhBDNF used for these experiments was tested on dopaminergic neurons in culture and found to stimulate dopamine uptake with a potency similar to that of our earlier studies and a report by other investigators (Fig. 5) (Hyman et al., 1991; Knüsel et al., 1991). Several injection regimens wcre utilized to test for possiblc rhBDNF-mediated protection of dopaminergic cell bodies after MFB transections in adult rats. A first series followed one of the injection regimens found to be effective for the cholinergic system. MFB-lesioned animals received $0.58 \mu \mathrm{g}$ of rhBDNF in $2.5 \mu \mathrm{l}$ into the lateral ventricle every second day during $18 \mathrm{~d}$ (total of $5.2 \mu \mathrm{g}$ per animal). Standardized cell counting failed to reveal any protective effect of this treatment on TH-positive cell bodies in the substantia nigra or the medioventral mesencephalic area (Table 2, Fig. 6). The total number of cell bodies and their distribution on the lesioned side were identical to that of rats treated with the control protein. No significant effect of rhBDNF treatment was observed on the number of TH-positive cell bodies on unlesioned sides. Detailed visual inspection of stained sections failed to reveal any change in staining intensity or size of TH-positive cell bodies induced by rhBDNF treatment.

The septal area is surrounded by ventricular fluid, whereas the ventral mesencephalon is much less intimately related to the ventricular system. To test whether insufficient penetration of intraventricularly administered rhBDNF to possible receptors on dopaminergic cells might prevent a protective effect on these cells, two additional administration paradigms were used. First, $0.224 \mu \mathrm{g}$ of rhBDNF in $1 \mu \mathrm{l}$ was injected daily for $18 \mathrm{~d}$ at the site of the MFB lesion (total amount per animal, 4.03 $\mu \mathrm{g})$; second, the same amount and volume was injected daily for $18 \mathrm{~d}$ locally into the substantia nigra. These treatments were equally ineffective as intraventricular administration in exerting any protective effect on TH-positive cell bodies in the ventral mesencephalon (Table 2, Fig. 7).

\section{Discussion}

We demonstrate in the present study that intraventricular administration of rhBDNF in fimbria-lesioned rats significantly reduces degenerative changes of the cholinergic cells in the septal area. No such effect was seen for the dopaminergic neurons of the ventral mesencephalon. NGF was repeatedly shown to exert a protective effect on basal forebrain cholinergic neurons after partial or full fimbrial lesions (Hefti, 1986; Williams et al., 1986; Kromer, 1987; Gage et al., 1988; Montero and Hefti, 1988; Koliatsos et al., 1991), and rhNGF was used in the present study as a positive control protein. The protective effect of the intracerebroventricular injections of rhBDNF was only partial when compared against the number of cholinergic cell bodies on the unlesioned side, and when compared with the protective effect of an equal amount of rhNGF. Injecting amounts of rhBDNF or rhNGF, which, in a cell culture assay of embryonic basal forebrain cholinergic neurons, were determined to be equipotent for these neurons, resulted in similar or slightly lower protective effects of rhBDNF than of rhNGF for the axotomized cholinergic neurons. Therefore, since different dose requirements for rhNGF and rhBDNF were observed not only in vivo but also in vitro, they are unlikely to reflect differences in penetration into the tissue or different rates of clearance from the brain of the two trophic factors.

Several possibilities could explain different dose requirements or, possibly, maximal effects of rhBDNF and rhNGF in protecting cholinergic cell bodies. First, rhBDNF could act on a select subpopulation of BDNF-responsive cells. The finding that the anteroposterior distribution of protected cholinergic neurons is the same for rhBDNF and rhNGF, however, makes this an unlikely possibility. Second, rhBDNF could be less stable than rhNGF. Therefore, aliquots of the solutions of rhBDNF and 


\section{A}

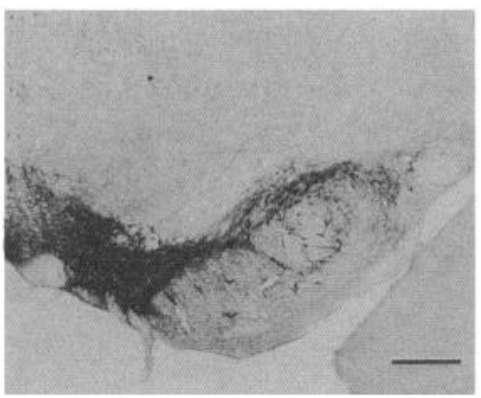

B
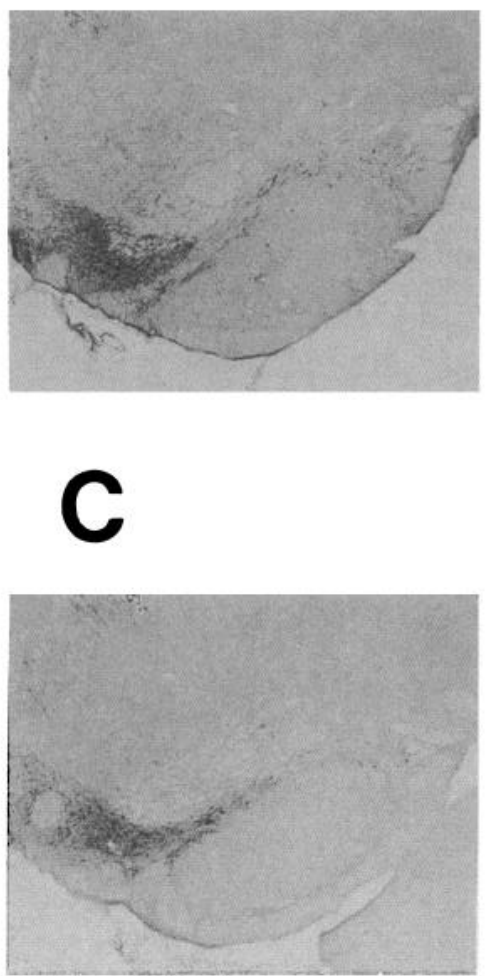
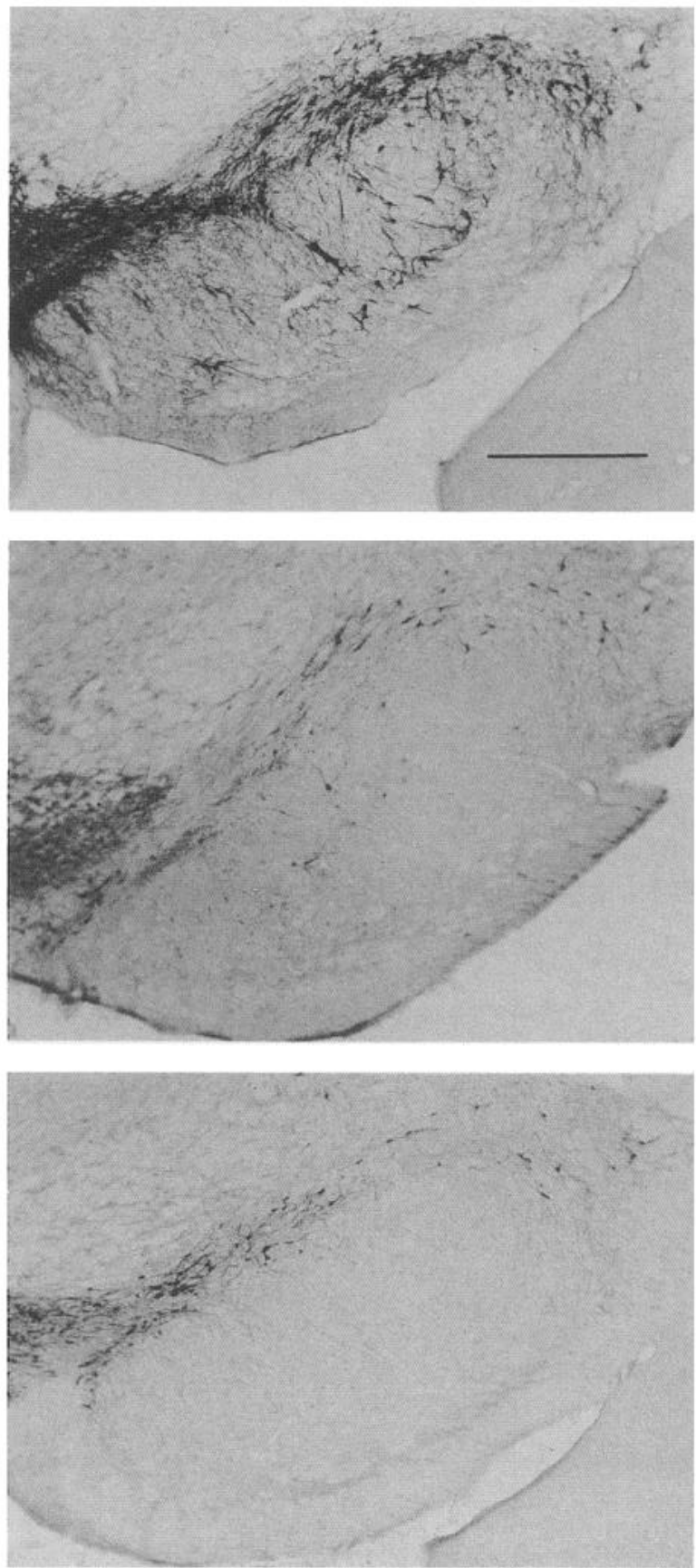

Figure 6. Photomicrographs of frontal sections through the ventral mesencephalon stained by TH immunohistochemistry. Rats received unilateral transections of the MFB resulting in axonal transection of dopaminergic neurons in the substantia nigra. $A$, unlesioned side; $B$, lesioned side of animal treated with intraventricular infusions of cytochrome C (control); $C$, lesioned side of rhBDNF-treated animal ( 0.58 $\mu \mathrm{g}$ intraventricularly every second day). The lesion induces a pronounced loss of TH-positive cell bodies in substantia nigra and ventral mesencephalic area. Scale bars, $500 \mu \mathrm{m}$.
rhNGF that were used for the daily injections were tested for bioactivity in basal forebrain cultures after completion of the injections. Both proteins were found to be still fully active. Third, functional receptors for BDNF on basal forebrain cholinergic neurons could have binding constants, or occupancy requirements for a full biological response different from the high-affinity receptor for NGF. It seems interesting in this context that for $t r k \mathrm{~B}$, but not for $t r k$, a variant of the mRNA has been found that lacks the intracellular structure of a tyrosine protein kinase, believed to be involved in signal transduction (Klein et al., 1990a; Kaplan et al., 1992). Further, while the proteins of the trk family have been shown to be receptors for the different neurotrophins, the involvement of accessory proteins like 1-NGFR in determining binding characteristics and functional properties of specific and biologically functional neu- rotrophin receptors is still unclear. Fourth, the reduced effect of rhBDNF could indicate an indirect action on the cholinergic neurons. rhBDNF could act on other cells in the hippocampus, neurons, or glia, which then would indirectly increase cholinergic cell survival, possibly by increased production and release of endogenous NGF. In contrast, the fast and pronounced, most likely direct response to rhBDNF of basal forebrain cholinergic neurons in culture might reflect a developmental function of this growth factor for these neurons (Alderson et al., 1990; Knüsel et al., 1991). Fifth, the protective effect of rhBDNF could be mediated by receptors for other neurotrophins. It remains to be established whether adult basal forebrain cholinergic neurons retain functional BDNF receptors. So far, high-affinity BDNF binding sites or mRNA for the presumptive BDNF receptor protein $t r k \mathrm{~B}$ have not been reported to occur in adult basal 


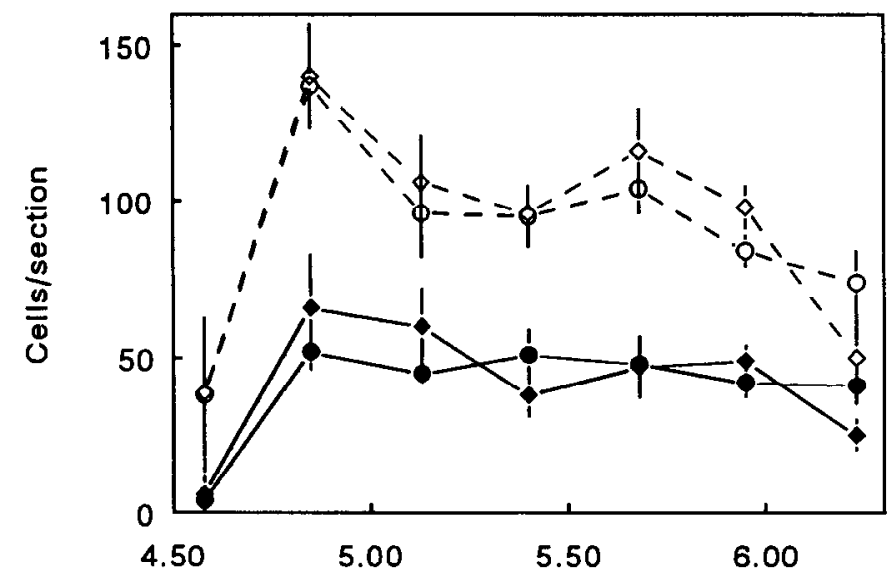

DISTANCE FROM BREGMA $(\mathrm{mm})$

Figure 7. Anteroposterior distribution of $\mathrm{TH}$-positive neurons within the substantia nigra (areas $A 9+A 8$ ). rhBDNF does not diminish the lesion-induced loss of TH-positive cell bodies in the substantia nigra. The animals were injected intracerebroventricularly every second day with $0.58 \mu \mathrm{g}$ of cytochrome $\mathrm{C}$ (controls) or rhBDNF. After $18 \mathrm{~d}$, the animals were killed and the $\mathrm{TH}$-positive cell bodies in dopaminergic areas $\mathrm{A} 8$ and $\mathrm{A} 9$ were counted after $\mathrm{TH}$ immunostaining. Unlesioned side: 0 , control; $\diamond$, rhBDNF. Lesioned side: $\bullet$, control; $\diamond$, rhBDNF. Means \pm SEM are shown; numbers of animals per group are as given in Table 2.

forebrain cholinergic neurons. Even though the rhBDNF response of developing cholinergic neurons most likely is not mediated by NGF receptors (Knüsel et al., 1991), such a mechanism presently cannot be excluded for the response of adult cholinergic neurons reported here.

The difference in potency between rhBDNF and rhNGF for their effects on basal forebrain cholinergic neurons in culture amounts to one to two orders of magnitude, and the dose requirements for rhBDNF are very similar for cholinergic and dopaminergic neurons in culture (Knüsel et al., 1991; present results). It could be argucd that the rclatively low potency of rhBDNF is a consequence of poor biological activity of the rhBDNF used in our studies. However, this conclusion is not supported by the following findings. First, in assays of chick dorsal root ganglion (DRG) cell survival in culture, the rhBDNF protein used in our study was found to be very similarly potent as rhNGF (Rosenthal et al., 1991). Second, the potency of the rhBDNF used in our studies is essentially identical to that of recombinant BDNF produced by another research group (Alderson et al., 1990; Suter et al., 1992). The potency of both preparations of recombinant BDNF in supporting survival of DRG neurons is in the range of reported potencies for purified pig brain BDNF, that is, $5 \mathrm{ng} / \mathrm{ml}$ (Lindsay et al., 1985) and 80 $\mathrm{pg} / \mathrm{ml}$ (Rodriguez-Tebar and Barde, 1988). This wide range of reported $\mathrm{EC}_{50}$ values for purified brain $\mathrm{BDNF}$ leaves open the question of whether rhBDNF might be less active on rat brain neurons than native pig BDNF. Given the high degree of conservation of molecular sequence among different mammalian species, this seems unlikely but should be addressed by future studies. In the case of NGF, where native protein is more readily available, no such difference has been found (Knüsel et al., 1990b). Our findings are in line with those obtained by Alderson, Suter, and collaborators, who also found different dose-response requirements between DRG neuron survival and ChAT stimulation of forebrain cholinergic neurons. Therefore, the pres- ently available data suggest that the mechanisms of stimulation by rhBDNF of basal forebrain cholinergic neurons and chick DRG cells are different, possibly involving different specific receptor configurations. This question needs to be addressed by in vitro studies, ideally by directly investigating receptor actions of the trophic proteins.

Interestingly, the partial protection exerted by rhBDNF treatment on lesioned cholinergic neurons is comparable to that observed after intraventricular administration of basic fibroblast growth factor (bFGF; Anderson et al., 1988; Schwaber et al., 1991). Also, in cell cultures, extent and time windows of responsiveness of cholinergic neurons are very similar for bFGF and rhBDNF (Knüsel et al., 1990a, 1991). These findings support the speculation that biological actions mediated by bFGF and BDNF receptors in these neurons are very similar. However, while bFGF actions on developing cholinergic neurons appear to be mediated by direct actions on these cells (Knüsel et al., 1990a), no mRNA for bFGF receptors or bFGF seems to be present in these neurons in the adult rat (Wanaka et al., 1990). The effects of intraventricular administration of bFGF are likely to be mediated by other cells, for example astrocytes, in which the synthesis of NGF and, possibly, other neurotrophins can be activated by bFGF (Spranger et al., 1990; Yoshida and Gage, 1991).

Intracerebral administration of NGF has been proposed as experimental treatment for Alzheimer's disease (Phelps et al., 1989), and initial trials are in progress (Olson, 1991). Our results suggest that administration of BDNF might also have to be considered in this context. Since NGF is more potent and, possibly, more effective than BDNF in protecting cholinergic neurons, NGF remains the protein of choice for interventions aiming at the basal forebrain cholinergic neurons. However, the combination of BDNF and NGF may be more effective than NGF alone. In cell culture experiments, combined application of rhBDNF and rhNGF at selected times of development of the cholinergic basal forebrain neurons produces additive effects on ChAT activity (Knüsel et al., 1991; B. Knüsel, unpublished observations). It seems possible that combined application in vivo might result in a more robust protection of lesioned cholinergic neurons and enhancement of cholinergic function in the remaining cholinergic fibers that project through the unlesioned part of the fimbria in our partial lesion model. Chronic treatment with NGF increases ChAT activity in the partially denervated hippocampus and increases the capacity of hippocampal slices to synthesize and release ACh (Hefti et al., 1984; Williams et al., 1989; Lapchak and Hefti, 1991; Lapchak et al., 1992). NGF injections also accelerate the behavioral recovery of fimbrialesioned rats in learning experiments in a radial maze (Will and Hefti, 1985). In contrast to the pronounced stimulatory actions of NGF on hippocampal cholinergic function, intraventricular treatment with rhBDNF did not increase ACh synthesis (Lapchak and Hefti, 1992). However, it needs to be tested whether BDNF or BDNF combined with NGF is able to improve further some of the parameters affected by NGF administration.

While providing a basis for the eventual pharmacological use of neurotrophic factors, administration of growth factors to animals with experimental lesions can also provide information about the physiological function of neurotrophic factors in the adult brain. Axonal transection of cholinergic neurons results in various degrees of degenerative changes, ranging from mild atrophy, shrinkage associated with downregulation of markers, to degeneration of the cell body (Daitz and Powell, 1954; Gage 
et al., 1986; Hefti, 1986; Hagg et al., 1988, 1989; Montero and Hefti, 1988; O'Brien et al., 1990; Tuszynski et al., 1990). The distance of the lesion to the cell body seems to be a major determinant for the extent of the degenerative changes (Sofroniew and Isacson, 1988). Recent findings by Sofroniew et al. (1990) do not support the notion that hippocampal NGF is necessary for survival of cholinergic neurons. Complete destruction, in this study, of the hippocampal neuronal cells, without transection of the cholinergic axons, failed to induce loss of septal cholinergic cell bodies. The function of endogenous hippocampal NGF in the adult remains an enigma. The coexistence of mRNA for NGF, BDNF, and also NT-3 in the hippocampus is striking (Phillips et al., 1990; Wetmore et al., 1990; Friedman et al., 1991). It can be speculated that the protective effects of exogenous NGF and BDNF that are observed in the fimbria lesion model represent a pharmacological action on injured neurons reflecting normally different physiological functions. Neurotrophins in the adult hippocampus might control biochemical or morphological modifications at a subcellular level. In cultures of sympathetic neurons, local NGF administration stimulates growth of those neurites exposed to NGF (Campenot, 1982a,b, 1987). Endogenous NGF and BDNF may stimulate cholinergic neurite growth or, alternatively, the functional performance of cholinergic terminals, in local areas with elevated synaptic activity as suggested by the elevated hippocampal NGF and BDNF expression after kainate-induced seizures (Gall and Isackson, 1989; Zafra et al., 1990, 1991; Isackson et al., 1991). However, similar experiments with early postnatal rats do not show a direct coupling of electrical activity with expression of BDNF mRNA (Dugich-Djordjevic et al., 1992). Irrespective of their relationships to the firing rate of a neuron, endogenous neurotrophins may play a role in establishing and stabilizing functional synaptic contacts between responsive axons and their target cells. Such mechanisms could be specially prominent in basal forebrain cholinergic neurons, since these cells are instrumental in memory processes (for reviews, see Squire and Davis, 1981; Singh et al., 1985; Dekker et al., 1991).

rhBDNF administration failed to protect axotomized dopaminergic neurons, although the same trophic factor enhances dopaminergic development of cultures of the ventral mesencephalon (Hyman et al., 1991; Knüsel et al., 1991). Cell culture studies were part of the initial evidence that NGF acts on basal forebrain cholinergic neurons (Honegger and Lenoir, 1982; Hefti et al., 1985) and provided the basis for experiments in which NGF was administered to adult animals with experimental lesions. While primary cultures of embryonic brain cells as used in these studies are most relevant for exploring possible roles of neurotrophic factors during development, they also can serve as predictors to identify responsive cell populations in the adult organism. NGF in cell cultures selectively promotes differentiation of peripheral sympathetic, basal forebrain cholinergic, but not mesencephalic dopaminergic neurons (Dreyfus et al., 1980; Knüsel et al., 1990a,b). In adult rats, NGF protects lesioninduced degenerative changes of sympathetic neurons (Ruit et al., 1990), and forebrain cholinergic cells but not mesencephalic dopaminergic neurons (Hefti, 1989). In contrast, the present study reveals a striking difference between effects of rhBDNF application in vitro and in vivo, which can be due to several reasons. First, dopaminergic neurons could express functional BDNF receptors in a transitory way during development only. Second, the stimulatory effect in the cell cultures could be indirect, mediated by glial cells or other cells in the cultures, which in the lesioned brain might not be present in sufficient numbers or proper location to exert a similar effect. Third, the procedure of dissociating and culturing the embryonic tissue could induce BDNF responsiveness in dopaminergic cells that normally might not be present. Alternatively, lack of effect of rhBDNF could be technical, due to inability to diffuse to the appropriate receptors in the brain parenchyma. However, our findings that local administration of the factor at the sitc of the lesion or within the substantia nigra also fails to protect dopaminergic neurons disprove this assumption. Similar discrepancy between in vitro and in vivo findings as for rhBDNF was earlier found for insulin, which promotes cholinergic and dopaminergic differentiation in culture (Knüsel et al., 1990a,b) but fails to prevent degenerative change of these cells in adult brains after axotomy (Hefti, 1989; F. Hefti, unpublished observations). Cell culture systems, therefore, seem to indicate possible but not necessarily occurring responses of adult neurons. Nevertheless, they remain a very valuable tool allowing the investigator to test large numbers of potentially active molecules and to select those with greatest promise for in vivo activity.

Our study provides evidence that intracerebral rhBDNF administration significantly reduces degeneration of basal forebrain cholinergic neurons after axonal transection, but is unable to protect axotomized dopaminergic neurons. However, these findings do not generally exclude any responsiveness of adult dopaminergic neurons to BDNF. It remains to be seen whether the positive findings obtained in dopaminergic cell cultures might reflect BDNF effects on parameters like transmitter function or axonal and dendritic growth of dopaminergic neurons. Such actions might become visible only after experimental treatments that compromise the functional or structural integrity of these cells but that are less disruptive than axonal transection.

\section{References}

Agid Y (1991) Parkinson's disease: pathophysiology. Lancet 337:13211327.

Agnati LF, Fuxe K, Calza L, Benfenati F, Cavicchioli L, Toffano G, Goldstein M (1983) Gangliosides increase the survival of lesioned nigral dopamine neurons and favor the recovery of dopaminergic synaptic function in striatum of rats by collateral sprouting. Acta Physiol Scand 199:347-363.

Albin RL, Young AB, Penney JB (1989) The functional anatomy of basal ganglia disorders. Trends Ncurosci 12:366-375.

Alderson RF, Alterman AL, Barde YA, Lindsay RM (1990) Brainderived neurotrophic factor increases survival and differentiated functions of rat septal cholinergic neurons in culture. Neuron 5:297-306.

Anderson KJ, Dam D, Lee S, Cotman CW (1988) Basic fibroblast growth factor prevents death of lesioned cholinergic neurons in vivo. Nature 332:360-362.

Ayer-LeLievre C, Olson L, Ebendahl T, Seiger A, Persson H (1988) Expression of the beta-nerve growth factor gene in hippocampal neurons. Science 240:1339-1341.

Barde Y-A (1989) Trophic factors and neuronal survival. Neuron 2: $1525-1534$.

Beck KD, Knüsel B, Winslow JW, Rosenthal A, Burton LE, Nikolics K, Hefti F (1992) Pretreatment of dopaminergic neurons in culture with brain-derived neurotrophic factor attenuates toxicity of 1 -methyl-4-phenylpyridinium. Neurodegeneration 1:27-36.

Bothwell M (1991) Keeping track of neurotrophin receptors. Cell 43: 915-918.

Buck CR, Martinez HJ, Black IB, Chao MV (1987) Developmentally regulated expression of the nerve growth factor receptor gene in the periphery and brain. Proc Natl Acad Sci USA 84:3060-3063.

Campenot RB (1982a) Development of sympathetic neurons in compartmentalized cultures. I. Local control of neurite growth by nerve growth factor. Dev Biol 93:1-12.

Campenot RB (1982b) Development of sympathetic neurons in com- 
partmentalized cultures. II. Local control of neurite survival by nerve growth factor. Dev Biol 93:13-21.

Campenot RB (1987) Local control of neurite sprouting in cultured sympathetic neurons by nerve growth factor. Dev Brain Res 37:293301.

Daitz HM, Powell TPS (1954) Studies on the connections of the fornix system. J Neurol Neurosurg Psychiatry 17:75-82.

Dekker AJAM, Connor DJ, Thal LJ (1991) The role of cholinergic projections from the nucleus basalis in memory. Neurosci Biobehav Rev 15:299-317.

Dreyfus CF, Peterson ER, Crain SM (1980) Failure of nerve growth factor to affect fetal mouse brain catecholaminergic neurons in culture. Brain Res 194:540-547.

Dugich-Djordjevic MM, Tocco G, Lapchak PA, Najm I, Pasinetti G, Thompson RF, Baudry M, Hefti F (1992) BDNF mRNA expression in the developing rat brain following kainic acid-induced seizure activity. Neuron, in press.

Ernfors P, Wetmore C, Olson L, Persson H (1990) Identification of cells in rat brain and peripheral tissues expressing mRNA for members of the nerve growth factor family. Neuron 5:511-526.

Fallon JH, Loughlin SE (1985) Substantia nigra. In: The rat nervous system, Vol 1 (Paxinos G, ed), pp 353-374. Sydney: Academic.

Friedman WJ, Ernfors P, Persson H (1991) Transient and persistent expression of NT-3/HDNF $\mathrm{mRNA}$ in the rat brain during postnatal development. J Neurosci 11:1577-1584.

Gage FH, Wictorin K, Fischer W, Williams LR, Varon S, Bjorklund A (1986) Life and death of cholinergic neurons: in the septal and diagonal band region following complete fimbria fornix transections. Neuroscience 19:241-256.

Gage FH, Armstrong DM, Williams LR, Varon S (1988) Morphological response of axotomized septal neurons to nerve growth factor. J Comp Neurol 269:147-155.

Gall CM, Isackson PJ (1989) Limbic seizures increase neuronal production of messenger RNA for nerve growth factor. Science 245:758761

Glass DJ, Nye SH, Hantzopoulos P, Macchi MJ, Squinto SP, Goldfarb $M$, Yancopoulos GD (1991) TrkB mediates BDNF/NT-3-dependent survival and proliferation in fibroblasts lacking the low affinity NGF receptor. Cell 66:405-413.

Hagg T, Manthorpe M, Vahlsing HL, Varon S (1988) Delayed treatment with nerve growth factor reverses the apparent loss of cholinergic neurons after acute brain damage. Exp Neurol 101:303-312.

Hagg T, Fass-Holmes B, Vahlsing HL, Manthorpe M, Conner JM, Varon S (1989) Nerve growth factor (NGF) reverses axotomy-induced decreases in choline acetyltransferase, NGF receptor and size of medial septum cholinergic neurons. Brain Res 505:29-38.

Hefti F (1986) Nerve growth factor (NGF) promotes survival of septal cholinergic neurons after fimbrial transections. J Neurosci 6:21552162.

Hefti F (1989) Nerve growth factor and neurotrophic factors in Parkinson's disease and aging. In: Parkinsonism and aging (Calne DB, Comi G, Crippa D, Horowski R, Trabucchi M, eds), pp 79-88. New York: Raven.

Hefti F, Mash DC (1989) Localization of nerve growth factor receptors in the normal human brain and in Alzheimer's disease. Neurobiol Aging 10:75-87.

Hefti F, David A, Hartikka J (1984) Chronic intraventricular injections of nerve growth factor elevate hippocampal choline acetyltransferase activity in adult rats with partial septo-hippocampal lesions. Brain Res XX:293-311.

Hefti F, Hartikka J, Eckenstein F, Gnahn H, Heumann R, Schwab M (1985) Nerve growth factor (NGF) increases choline acetyltransferase but not survival or fiber outgrowth of cultured fetal septal cholinergic neurons. Neuroscience 14:55-68.

Hefti F, Hartikka J, Salvatierra A, Weiner WJ, Mash DC (1986) Localization of nerve growth factor receptors in cholinergic neurons of the human basal forebrain. Neurosci Lett 69:37-41.

Hefti F, Hartikka J, Knüsel B (1989) Function of neurotrophic factors in the adult and aging brain and their possible use in the treatment of neurodegenerative diseases. Neurobiol Aging 10:515-533.

Higgins GA, Koh S, Chen KS, Gage FH (1989) Nerve growth factor (NGF) induction of NGF receptor gene expression and cholinergic neuronal hypertrophy within the basal forebrain of the adult rat. Neuron 3:247-256.
Hofer M, Pagliusi SR, Hohn A, Leibrock J, Barde YA (1990) Regional distribution of brain-derived neurotrophic factor mRNA in the adult mouse brain. EMBO J 9:2459-2464.

Hofer MM, Barde YA (1988) Brain-derived neurotrophic factor prevents neuronal death in vivo. Nature 331:261-262.

Honegger P, Lenoir D (1982) Nerve growth factor (NGF) stimulation of cholinergic telencephalic neurons in aggregating cell cultures. Dev Brain Res 3:229-239.

Hyman C, Hofer M, Barde YA, Juhasz M, Yancopoulos GD, Squinto SP, Lindsay RM (1991) BDNF is a neurotrophic factor for dopaminergic neurons of the substantia nigra. Nature 350:230-233.

Isackson PJ, Huntsman MM, Murray KD, Gall CM (1991) BDNF mRNA expression is increased in adult rat forebrain after limbic seizures: temporal patterns of induction distinct from NGF. Neuron 6:937-948.

Johnson JE, Barde Y-A, Schwab M, Thoenen H (1986) Brain-derived neurotrophic factor supports the survival of cultured rat retinal ganglion cells. J Neurosci 6:3031-3038.

Kaplan DR, Hempstead BL, Martin-Zanca D, Chao MV, Parada LF (1991a)The trk proto-oncogene product: a signal transducing receptor for nerve growth factor. Science 252:554-558.

Kaplan DR, Martin-Zanca D, Parada LF (1991b) Tyrosine phosphorylation and tyrosine kinase activity of the $t r k$ proto-oncogene product induced by NGF. Nature 350:158-160.

Kaplan DR, Perkins A, Morrison DK (1992) Signal transduction by receptor tyrosine kinases. Oncogene, in press.

Klein R, Conway D, Parada LF, Barbacid M (1990a) The trkB tyrosine protein kinase gene codes for a second neurogenic receptor that lacks the catalytic kinase domain. Cell 61:647-656.

Klein R, Martin-Zanca D, Barbacid M, Parada LF (1990b) Expression of the tyrosine kinase receptor gene trkB is confined to the murine embryonic and adult nervous system. Development 109:845-850.

Klein R, Nanduri V, Jing S, Lamballe F, Tapley P, Bryant S, CordonCardo C, Jones KR, Reichardt LF, Barbacid M (1991) The trkB tyrosine protein kinase is a receptor for brain-derived neurotrophic factor and neurotrophin-3. Cell 66:395-404.

Knüsel B, Michel PP, Schwaber J, Hefti F (1990a) Selective and nonselective stimulation of central cholinergic and dopaminergic development in vitro by nerve growth factor, basic fibroblast growth factor, epidermal growth factor, insulin and the insulin-like growth factors I and II. J Neurosci 10:558-570.

Knüsel B, Burton LE, Longo FM, Mobley WC, Koliatsos VE, Price DL Hefti F (1990b) Trophic actions of recombinant human nerve growth factor on cultured rat embryonic CNS cells. Exp Neurol 110:274 283.

Knüsel B, Winslow JW, Rosenthal A, Burton LE, Seid DP, Nikolics K, Hefti $F$ (1991) Promotion of central cholinergic and dopaminergic neuron differentiation by brain-derived neurotrophic factor but not neurotrophin-3. Proc Natl Acad Sci USA 88:961-965.

Koliatsos VE, Applegate MD, Knüsel B, Burton LE, Mobley WC, Hefti $F$, Price DL (1991) Recombinant human nerve growth factor prevents retrograde degeneration of axotomized basal forebrain cholinergic neurons in the rat. Exp Neurol 112:161-173.

Kordower JH, Bartus RT, Bothwell M, Schatteman G, Gash DM (1988) Nerve growth factor immunoreactivity in the non-human primate (Cebus apella): distribution, morphology, and colocalization with cholinergic enzymes. J Comp Neurol 277:465-486.

Korsching S, Auburger G, Heumann R, Scott J, Thoenen H (1985) Levels of nerve growth factor and its MRNA in the central nervous system of the rat correlate with cholinergic innervation. EMBO J 4: 1389-1393.

Kromer LF (1987) Nerve growth factor treatment after brain injury prevents neuronal death. Science 235:214-216.

Lapchak PA, Hefti F (1991) Effect of recombinant human nerve growth factor on presynaptic cholinergic function in rat hippocampal slices following partial septo-hippocampal lesions: measures of [3H]acetylcholine synthesis, [3H]acetylcholine release and choline acetyltransferase activity. Neuroscience 42:639-649.

Lapchak PA, Hefti F (1992) BDNF and NGF administration in fimbriectomized rats: effects on cholinergic function and weight gain. Neuroreport 3:405-408.

Lapchak PA, Jenden DJ, Hefti F (1992) Pharmacological stimulation reveals NGF-induced increases of hippocampal cholinergic function 
measured in vivo in rats with partial fimbrial transections. Neuroscience, in press.

Leibrock J, Lottspeich F, Hohn A, Hofer M, Hengerer B, Masiakowski P, Thoenen H, Barde Y-A (1989) Molccular cloning and expression of brain-derived neurotrophic factor. Nature 341:149-152.

Lindsay RM, Thoenen H, Barde Y-A (1985) Placode and neural crestderived sensory neurons are responsive at early developmental stages to brain-derived neurotrophic factor (BDNF). Dev Biol 112:319-328.

Lindvall O, Bjorklund A (1983) Dopamine and norepinephrine containing neuron systems: their anatomy in the rat brain, pp 229-255. New York: Raven.

Maisonpierre PC, Belluscio L, Friedman B, Alderson RF, Wiegand SJ, Furth RF, Lindsay R, Yancopoulos G (1990) NT-3, BDNF, and NGF in the developing rat nervous system: parallel as well as reciprocal patterns of expression. Neuron 5:501-509.

Marsden CD (1990) Parkinson's disease. Lancet 335:948-952.

Martin-Zanca D, Barbacid M, Parada LF (1990) Expression of the $t r k$ proto-oncogene is restricted to the sensory cranial and spinal ganglia of neural crest origin in mouse development. Genes Dev 4:683-694.

McKinney J, Coyle J, Hedreen JC (1983) Topographic analysis of the innervation of the rat neocortex and hippocampus by the basal forebrain cholinergic system. J Comp Neurol 217:103-121.

Montero CN, Hefti F (1988) Rescue of lesioned septal cholinergic neurons by nerve growth factor: specificity and requirement for chronic treatment. J Neurosci 8:2986-2999.

O'Brien TS, Svendsen CN, Isacson O, Sofroniew MV (1990) Loss of True blue labelling from the medial septum following transection of the fimbria-fornix: evidence for the death of cholinergic and noncholinergic neurons. Brain Res 508:249-256.

Olson L, Nordberg A, von Holst H, Backman L, Ebendahl T, Alafuzoff I, Amberla K, Hartvig P, Herlitz A, Lilja A, Lundquist H, Langstron B, Meyerson B, Persson A, Viitanen M, Winblad B, Seiger A (1992) Nerve growth factor affects $11 \mathrm{C}$-nicotine binding blood flow, EEG and verbal episodic memory in an Alzheimer patient. J Neurol Transm [P-D Sect] 4:79-95.

Olton DS (1990) Dementia: animal models of the cognitive impairments following damage to the basal forebrain cholinergic system. Brain Res Bull 25:499-502.

Oppenheim RW (1989) The neurotrophic theory and naturally occurring mononeuron death. Trends Neurosci 12:252-255.

Paxinos G, Watson C (1986) The rat brain in stereotaxic coordinates. London: Academic.

Phelps CH, Gage FH, Growdon JH, Hefti F, Harbaugh R, Johnston MV, Khachaturian ZS, Mobley WC, Price DL, Raskind M, Simpkins J, Thal LJ, Woodcock J (1989) Potential use of nerve growth factor to treat Alzheimer's disease. Neurobiol Aging 10:205-207.

Phillips HS, Hains JM, Laramee GR, Rosenthal A, Winslow JW (1990) Widespread expression of BDNF but not NT3 by target areas of basal forebrain cholinergic neurons. Science 250:290-292.

Price DL (1986) New perspectives on Alzheimer's disease. Annu Rev Neurosci 9:489-512.

Rennert PD, Heinrich G (1986) Nerve growth factor mRNA in brain: localization by in situ hybridization. Biochem Biophys Res Commun 138:813-818

Rodriguez-Tebar A, Barde Y-A (1988) Binding characteristics of brainderived neurotrophic factor to its receptors on neurons from the chick embryo. J Ncurosci 8:3337-3342.

Rodriguez-Tebar A, Dechant G, Barde Y-A (1990) Binding of brainderived neurotrophic factor to the nerve growth factor receptor. Neuron $4: 487-492$.

Rodriguez-Tebar A, Dechant G, Götz R, Barde Y-A (1992) Binding of neurotrophin-3 to its neuronal receptors and interactions with nerve growth factor and brain-derived neurotrophic factor. EMBO J 11: 917-922.

Rosenthal A, Goeddel DV, Nguyen T, Martin E, Burton LE, Shih A, Winslow JW (1991) Primary structure and biological activity of human brain-derived neurotrophic factor. Endocrinology 129:12891294.

Ruit KG, Osborne PA, Schmidt RE, Johnson EM, Snider WD (1990) Nerve growth factor regulates sympathetic ganglion cell morphology and survival in the adult mouse. $J$ Neurosci 10:2412-1418.

Schatteman GC, Gibbs L, Lanahan AA, Claude P, Bothwell M (1988) Expression of NGF receptor in the developing and adult primate central nervous system. J Neurosci 8:860-873.
Schwaber JS, Due BR, Rogers WT, Junard EO, Sharma A, Hefti F (1991) Use of digital brain atlas to compare the distribution of NGFand bFGF-protected cholinergic neurons. J Comp Neurol 309:1-13.

Shelton DL, Reichardt LF (1986) Studies on the expression of beta NGF gene in the central nervous system: level and regional distribution of NGF mRNA suggest that NGF functions as a trophic factor for several neuronal populations. Proc Natl Acad Sci USA 83:27142718.

Singh MM, Warburton DM, Lal H (1985) Central cholinergic mechanisms and adaptive dysfunctions. New York: Plenum.

Snider WD, Johnson EM Jr (1989) Neurotrophic molecules. Ann Neurol 26:489-506.

Sofroniew M, Galletly N, Isacson O, Svendsen C (1990) Survival of adult basal forebrain cholinergic neurons after loss of target neurons. Science 247:338-342.

Sofroniew MV, Isacson O (1988) Distribution of degeneration of cholinergic neurons in the septum following axotomy in different portions of the fimbria-fornix: a correlation between cell loss and proximity to the lesion. J Chem Neuroanat 1:327-337.

Soppet D, Escandon E, Maragos J, Kaplan DR, Hunter T, Nikolics K, Parada LF (1991) The neurotrophic factors BDNF and NT-3 are ligands for the trkB tyrosine kinase receptor. Cell 65:895-903

Spranger M, Lindholm D, Bandtlow C, Heumann R, Gnahn H, NaherNoe M, Thoenen $H$ (1990) Regulation of nerve growth factor (NGF) synthesis in the rat central nervous system: comparison between the effects of interleukin-1 and various growth factors in astrocyte cultures and in vivo. Eur J Neurosci 2:69-76.

Squinto SP, Stitt TN, Aldrich TH, Davis SM, Bianco SM, Rdziejewski C, Glass DJ, Masiakowski P, Furth ME, Valenzuela DM, DiStefano PS, Yancopoulos GD (1991) trkB encodes a functional receptor for brain-derived neurotrophic factor and neurotrophin-3 but not NGF. Cell 65:885-893.

Squire LR, Davis HP (1981) The pharmacology of memory: a neurobiological perspective. Annu Rev Pharmacol Toxicol 21:323-356.

Suter U, Angst C, Tien C-L, Drinkwater CC, Lindsay RM, Shooter E (1992) NGF/BDNF chimeric proteins: analysis of neurotrophin specificity by homolog-scanning mutagenesis. J Neurosci 12:306-318.

Thanos S, Bahr M, Barde YA, Vanselow J (1989) Survival and axonal elongation of adult rat retinal ganglion cells. In vitro effects of lesioned sciatic nerve and brain derived neurotrophic factor. Eur J Neurosci $1: 19-26$.

Thoenen H, Bandtlow C, Heumann R (1987) The physiological function of nerve growth factor in the central nervous system: comparison with the periphery. Rev Physiol Biochem Pharmacol 109:145-178.

Tuszynski MH, Armstrong DM, Gage FH (1990) Basal forebrain cell loss following fimbria/fornix transection. Brain Res 508:241-248.

Vantini G, Schiavo N, DiMartino A, Polato P, Triban C, Callegaro L Toffano G, Leon A (1989) Evidence for a physiological role of nerve growth factor in the central nervous system of neonatal rats. Neuron $3: 267-273$.

Vazquez ME, Ebendal T (1991) Messenger RNAs for trk and the lowaffinity NGF receptor in rat basal forebrain. Neuroreport 2:593-596.

Wanaka A, Johnson EM, Milbrandt J (1990) Localization of FGF receptor mRNA in the adult rat central nervous system by in situ hybridization. Neuron 5:267-281.

Wetmore C, Ernfors P, Persson H, Olson L (1990) Localization of brain-derived neurotrophic factor mRNAS to neurons in the brain by in situ hybridization. Exp Neurol 109:141-152.

Whittemore SR, Seiger $\Lambda$ (1987) The expression, localization and functional significance of beta-nerve growth factor in the central nervous system. Brain Res Rev 12:439-464.

Will B, Hefti F (1985) Behavioral and neurochemical effects of chronic intraventricular injections of nerve growth factor in adult rats with fimbria lesions. Behav Brain Res 17:17-24.

Williams LR, Varon S, Peterson GM, Wictorin K, Fischer W, Bjorklund A, Gage FH (1986) Continuous infusion of nerve growth factor prevents basal forebrain neuronal death after fimbria fornix transection. Proc Natl Acad Sci USA 83:9231-9235.

Williams LR, Jodelis KS, Donald MR (1989) Axotomy-dependent stimulation of choline acetyltransferase activity by exogenous mouse nerve growth factor in adult rat basal forebrain. Brain Res 498:243256.

Yan Q, Johnson EM (1988) An immunohistochemical study of the 
nerve growth factor receptor in developing rats. J Neurosci 8:34813498 .

Yoshida K, Gage FH (1991) Fibroblast growth factors stimulate nerve growth factor synthesis and secretion by astrocytes. Brain Res 538: $118-126$.

Zafra F, Hengerer B, Leibrock J, Thoenen H, Lindholm D (1990) Activity dependent regulation of BDNF and NGF mRNAs in the rat hippocampus is mediated by non-NMDA glutamate receptors. EMBO J 9:3545-3550.

Zafra F, Castren E, Thoenen H, Lindholm D (1991) Interplay between glutamate and gamma-aminobutyric acid transmitter systems in the physiological regulation of brain-derived neurotrophic factor and nerve growth factor synthesis in hippocampal neurons. Proc Natl Acad Sci USA 88:10037-10041. 